\title{
Oncolytic Measles Virus Encoding Thyroidal Sodium Iodide Symporter
}

National Cancer Institute

\section{Source}

National Cancer Institute. Oncolytic Measles Virus Encoding Thyroidal Sodium Iodide

Symporter. NCI Thesaurus. Code C66942.

An attenuated oncolytic Edmonston (Ed) strain of measles virus encoding the human thyroidal sodium iodide symporter (MV-NIS) with potential antineoplastic activity. The cellular receptor of MV is human CD46 antigen, a type 1 integral membrane glycoprotein found on nearly all human tissues and overexpressed on many cancer cell types. After attachment to and fusion of host cell membranes, MV-NIS induces syncytia and cell lysis. When combined with radioiodine 123 (I-123), expressed NIS facilitates uptake of I-123 into MV-infected cells, thereby allowing for noninvasive imaging of viral gene expression. MV-NIS also enhances the oncolytic activity of MV against radiosensitive tumor cells by additional destruction of the MV-infected cells when using iodine-131. 